\title{
PERANCANGAN DAN IMPLEMENTASI RAPID TEMPERATURE SCREENING CONTACTLESS DAN JUMLAH ORANG BERBASIS IOT DENGAN PROTOKOL MQTT
}

\author{
Dede Irawan Saputra ${ }^{1}$, Gian Melky Karmel ${ }^{2}$, Yuda Bakti Zainal ${ }^{3}$ \\ 1,2,3 Program Studi Teknik Elektro Universitas Jenderal Achmad Yani \\ Jl. Terusan Jenderal Sudirman, PO BOX 148 Kota Cimahi Indonesia \\ Email: dedeirawan.saputra@ lecture.unjani.ac.id ${ }^{1}$
}

\begin{abstract}
Tools for body temperature meters and tools to count the number of people in a building is needed to realize the health protocol created by the governmen. One of the developments in internet technology at this time is the Internet of Things. In this research, a system for monitoring body temperature and the number of people based on IoT with the MQTT protocol was designed. This system uses NodeMCU and makes it easier for the owner or supervisor of a building to find out how many people are in the building with an ultrasonik sensor and simultaneously check body temperature with the MLX 90614 sensor. Data on the number of people and body temperature are sent to the MQTT broker from the IoT Thingsboard platform which can later be accessed via Web User Interface. Thus this system can collect and diagnose the temperature and number of people in a building when entering a building. The test results of this system can read temperature changes and count the number of people using the MQTT protocol to the Thingsboard server and the data is displayed in the form of digital tables and gauges. Testing on the MLX90614 sensor with a thermometer gun displays a comparison with the difference in the average result of $0.5^{\circ} \mathrm{C}$, thus the $M L X 90614$ sensor can be used. The average time needed for the system to send data to the Thingsboard server is 0.44 seconds.
\end{abstract}

Keywords: Internet of Things, MQTT, NodeMCU, MLX 90614 Sensor

Abstrak

Kebutuhan pengukur suhu tubuh dan alat untuk menghitung jumlah orang dalam suatu gedung dibutuhkan untuk merealisasikan protokol kesehatan yang dibuat oleh pemerintah. Salah satu perkembangan teknologi internet pada saat ini adalah Internet of Things. Pada penelitian ini dirancang sistem pemeriksa suhu tubuh dan jumlah orang berbasis IoT dengan protokol MQTT. Sistem ini menggunakan NodeMCU dan memudahkan pemilik atau pengawas suatu gedung untuk mengetahui berapa jumlah orang dalam gedung dengan sensor ultrasonik dan sekaligus memeriksa suhu tubuh dengan sensor MLX 90614. Data jumlah orang dan suhu tubuh dikirim ke broker MQTT dari IoT platform Thingsboard yang nantinya dapat diakses melalui Web User Interface. Dengan demikian sistem ini dapat menghimpun dan mendiagnosis suhu dan jumlah orang dalam suatu gedung saat memasuki suatu gedung. Hasil pengujian sistem ini dapat membaca perubahan suhu dan menghitung jumlah orang menggunakan protocol MQTT ke server Thingsboard dan data di tampilkan dalam bentuk tabel dan pengukur digital. Pengujian pada sensor MLX90614 dengan thermometer gun menampilkan perbandingan dengan selisih hasil rata-rata $0,5^{\circ} \mathrm{C}$, dengan demikian sensor MLX 90614 dapat digunakan. Rata-rata waktu yang di butuhkan sistem untuk mengirim data ke server Thingsboard adalah 0,44 detik.

Kata Kunci: Internet of Things, MQTT, NodeMCU, Sensor MLX 90614, Sensor ultrasonic, Thingsboard.

\section{PENDAHULUAN}

Menularnya Covid-19 membuat dunia menjadi resah, termasuk di Indonesia. Covid-19 merupakan jenis virus yang baru sehingga banyak pihak yang tidak tahu dan tidak mengerti cara penanggulangan virus tersebut [1]. Seiring mewabahnya virus Corona atau Covid-19 ke ratusan negara, Pemerintah Republik Indonesia menerbitkan protokol kesehatan. Protokol tersebut akan dilaksanakan di seluruh Indonesia oleh pemerintah dengan dipandu secara terpusat oleh Kementerian Kesehatan RI [2].

Pemerintah menerbitkan protokol kesehatan yang wajib diterapkan di pusat perbelanjaan, kantor, hotel, hingga pusat keramaian lainnya, salah satunya adalah pemeriksaan suhu tubuh setiap pengunjung [3]. Untuk mengurangi penyebaran dan memutus rantai Covid-19 pemerintah menerapkan kebijakan sosial distancing. Masyarakat di himbau agar tidak berkerumun dan harus menjaga jarak 1 meter dengan orang di sekitarnya [4][5]. Di dalam ruangan pun hanya dibatasi beberapa orang saja. Kebutuhan pengukur suhu tubuh dan alat untuk menghitung jumlah orang dalam suatu gedung dibutuhkan untuk merealisasikan protokol kesehatan yang dibuat oleh pemerintah [6][7].

Umumnya disetiap gedung atau tempat keramaian seperti bandara, mall/pusat pembelanjaan pemeriksaan suhu tubuh menggunakan thermometer gun dan pembatasan pengunjung dalam ruangan hanya dihitung manual. Jika melakukuan perhitungan secara manual akan membutuhkan waktu dan memiliki resiko human erorr [8][9]. Berdasarkan hal tersebut maka diperlukan sistem untuk memeriksa suhu dan menghitung jumlah orang yang masuk dalam sebuah gedung secara real time agar dapat membantu dan menggantikan serta memudahkan petugas kemanan atau pengawas pintu masuk suatu gedung untuk memeriksa jumlah orang yang masuk dalam gedung serta memeriksa suhu perorangan sesaui dengan aturan pemerintah [10].

Salah satu solusi yang dapat digunakan adalah penggunaan Internet of Things (IoT) [11][12][13]. IoT dapat digunakan sebagai sarana pengumpulan data, dengan menggunakan beberapa protokol, diantaranya adalah HTTP, MQTT, CoAP [14]. Protokol MQTT memiliki beberapa kelebihan. Kelebihan dari protokol MQTT yaitu header lebih 
ringkas sehingga dapat menghemat sumber daya dan lebih ringan. Realisasi pemeriksaan suhu dapat menggunakan sensor MLX90614 kelebihannya dapat membaca suhu tubuh contactless tidak memerlukan kontak langsung antara tubuh dengan sensor [15][16] dan menghitung jumlah orang yang masuk ke sebuah gedung dapat menggunakan sensor ultrasonic kelebihannya [17], sedangkan untuk mengintegrasikan dengan sistem kontrol dapat menggunakan NodeMCU ESP8266 kelebihannya dapat menjalankan fungsi mikrokontroler dan juga koneksi internet [18][19].

Sistem ini diharapkan dapat memudahkan petugas keaman atau pengawas pintu masuk untuk menghitung jumlah orang dalam gedung dengan sensor ultrasonic [20] dan sekaligus memeriksa suhu tubuh dengan sensor MLX90614 [21]. Usulan penelitian ini dirancang sistem pemeriksa suhu tubuh dan jumlah orang berbasis IoT dengan protokol MQTT. Data jumlah orang dan suhu tubuh dikirim ke broker MQTT yang dapat diakses melalui website. Dengan demikian sistem ini dapat menghimpun dan mendiagnosis suhu dan jumlah orang dalam suatu gedung saat memasuki suatu gedung, sehingga sistem ini dapat membantu mendukung pemerintah dalam menerapkan protokol kesehatan.

\section{KAJIAN PUSTAKA}

\section{A. Sensor MLX90614}

Sensor MLX90614 merupakan sensor yang digunakan untuk mengukur suhu dengan memanfaatkan radiasi gelombang inframerah. Sensor MLX90614 yang ditunjukkan pada Gambar 1 didesain khusus untuk mendeteksi energi radiasi inframerah dan secara otomotis telah didesain sehingga dapat mengkalibrasikan energi radiasi inframerah menjadi skala temperatur. MLX90614 terdiri dari detektor thermopile inframerah MLX81101 dan signal conditioning ASSP MLX90302 yang digunakan untuk memproses keluaran dari sensor inframerah .Sensor MLX90614 merupakan sensor suhu contacless, artinya untuk mengukur temperatur, sensor ini tidak perlu bersentuhan langsung dengan objek tersebut [14]. Adapun spesifikasi dari sensor tersebut dapat ditunjukkan pada Tabel 1

Tabel 1. Spesifikasi sensor MLX90614

\begin{tabular}{|l|l|l|}
\hline No & Nama & Spesifikasi \\
\hline 1 & Power Supply & $3 \mathrm{~V}$ \\
\hline 2 & Respon time & $0,15 \mathrm{~s}$ \\
\hline 3 & Output PWM & Disesuaikan \\
\hline 4 & Wake up time & $80 \mathrm{~ms}$ \\
\hline
\end{tabular}

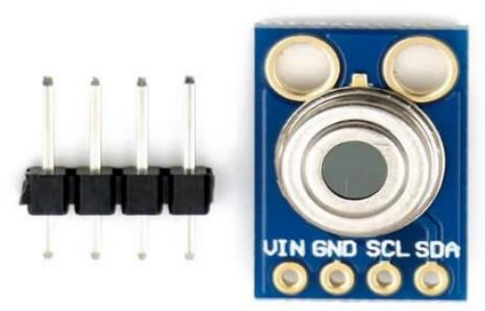

Gambar 1. Sensor MLX90614

\section{B. Sensor ultrasound HCSRO4}

HC-SR04 merupakan sensor ultrasonik siap pakai, satu alat yang berfungsi sebagai pengirim, penerima, dan pengontrol gelombang ultrasonik. Alat ini bisa digunakan untuk mengukur jarak benda dari $2 \mathrm{~cm}-4 \mathrm{~m}$ dengan akurasi $3 \mathrm{~mm}$ [16]. Berikut Gambar dan spesifikasi sensor yang ditunjukkan pada Gambar 2 dan Tabel 2.

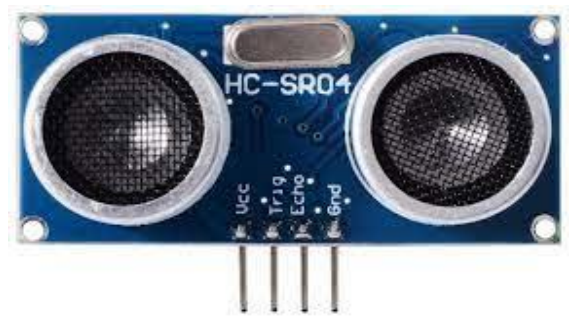

Gambar 2. Sensor HCSR04

Tabel 2. Spesifikasi sensor HCSR04

\begin{tabular}{|l|l|l|}
\hline No & Nama & Spesifikasi \\
\hline 1 & Power Supply & $+5 \mathrm{~V}$ DC \\
\hline 2 & Arus daya & $15 \mathrm{~mA}$ \\
\hline 3 & Sudut efektif & $<15^{\circ}$ \\
\hline 4 & Pembacaan jarak & $2 \mathrm{~cm}-400 \mathrm{~cm}$ \\
\hline 5 & Pengukuran sudut & $30^{\circ}$ \\
\hline
\end{tabular}

\section{Protokol MQTT}

MQTT merupakan sebuah protokol pertukaran pesan dengan model publish/subscribe yang sederhana dan ringan serta didesain untuk perangkat yang memiliki kemampuan terbatas dan bandwidth yang kecil, latency tinggi, atau jaringan yang tidak andal. MQTT memiliki karakteristik mentransfer data dalam paket ukuran rendah, dan ini sangat membantu untuk mengembangkan teknologi remote dengan perangkat terbatas . Prinsip desain MQTT adalah untuk meminimalisasi bandwidth jaringan dan kebutuhan resource perangkat dan tetap menjamin keandalan dan beberapa tingkat jaminan tersampaikannya sebuah pesan. Prinsip inilah yang membuat protokol ini ideal untuk diaplikasikan pada komunikasi machine-to-machine (M2M) atau Internet of Things dan untuk aplikasi mobile dimana bandwidth dan kapasitas baterai terbatas.

Spesifikasi protokol MQTT telah dipublikasikan secara terbuka dengan lisensi open-source. Pertukaran pesan dengan model publish/subscribe pada MQTT merupakan alternatif dari model client-server, dimana sebuah client (publisher/subscriber) berkomunikasi langsung dengan sebuah endpoint lainnya pada sebuah topik melalui sebuah broker yang bertugas melakukan penyaringan pesan dan mendistribusikannya. Broker pada MQTT berfungsi untuk menghandle data publish dan subscribe dari berbagai device, bisa diibaratkan sebagai server yang memiliki alamat IP khusus. Beberapa contoh dari Broker yang ada seperti Mosquitto, HiveMQ. Publish merupakan cara suatu device untuk mengirimkan datanya ke subscribers. Biasanya pada publisher ini adalah sebuah device yang terhubung dengan sensor tertentu. Subscribe merupakan cara suatu device untuk menerima berbagai macam data dari publisher. Subscriber dapat berupa aplikasi monitoring sensor dan sebagainya, subscriber ini yang nantinya akan meminta data 
dari publisher, jika klien yang menginginkan menerima pesan, bisa meng-subscribe ke suatu topic tertentu dan broker akan mengirimkan semua message yang cocok dengan pola (pattern) topic tersebut kepada client yang sesuai.

Mekanisme tersebut membuat klien tidak perlu untuk tau satu sama lain untuk bisa berkomunikasi, melainkan mereka cukup berkomunikasi menggunakan topic. Topic seperti halnya pengelompokan data disuatu kategori tertentu. Pada sistem kerja MQTT protokol ini, topic bersifat wajib hukumnya. Pada setiap transaksi data antara Publisher dan Subscriber harus memiliki suatu topic tertentu. MQTT publisher dapat mengirimkan pesan berbasis topic kepada MQTT broker lalu MQTT broker akan menerima pesan yang dikirimkan oleh MQTT publisher. MQTT subscriber dapat melakukan subscribe pada topik yang diinginkan dan yang di kehendaki oleh pengguna kepada MQTT broker lalu setelah di subscribe maka MQTT broker dapat menyampaikan pesan dari MQTT publisher kepada MQTT subscriber [25]. Berikut diagra arsiektur Protokol MQTT yang ditunjukkan pada Gambar 3.

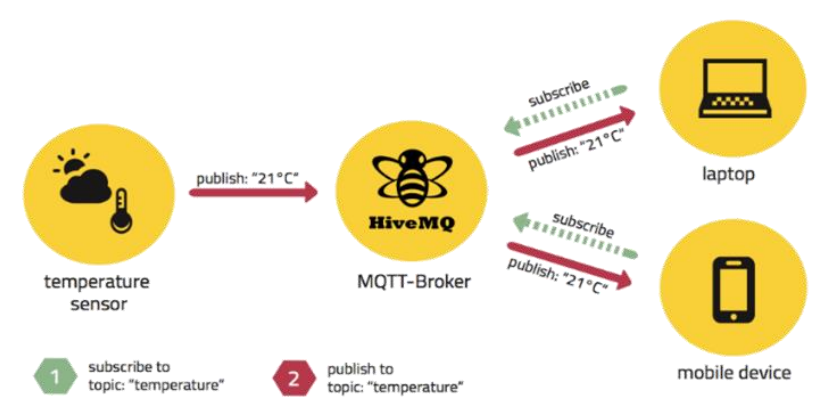

Gambar 3. Arsitektur MQTT

\section{METODE}

A. Diagram Blok Sistem

Berikut ini pada Gambar 4 adalah diagram blok sistem pada sistem pemeriksaan suhu dan jumlah orang masuk.

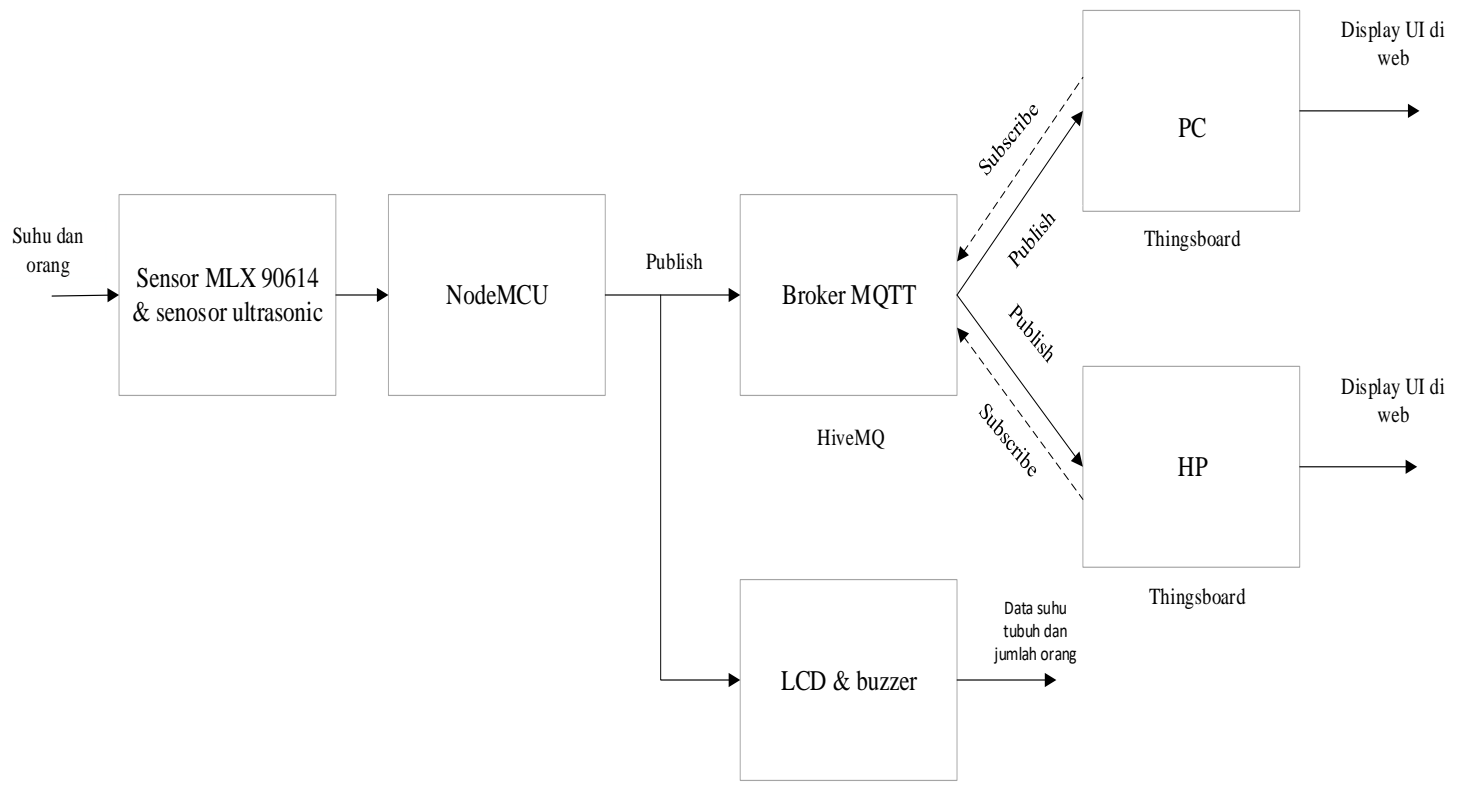

Gambar 4. Diagram blok sistem

Pada diagram blok sistem yang ditunjukkan pada Gambar 1 memiliki dua buah input yaitu suhu tubuh dan orang yang akan di deteksi menggunakan sensor MLX90614 dan sensor ultrasonik. Sensor MLX90614 merupakan sebuah sensor yang mendeteksi suhu dari orang yang akan memasuki gedung. sensor ultrasonik digunkan untuk mendeteksi dan menghitung jumlah orang yang masuk ke dalam gedung. Kontroler yang digunakan pada penelitian adalah NodeMCU, NodeMCU akan menerima data dari sensor MLX90614 dan ultrasonik untuk dikirimkan ke broker MQTT. NodeMCU juga terdapat modul WiFi yang dapat terkoneksi dengan internet untuk dapat mengirimkan data melalui jaringan internet. LCD digunuakan untuk menampilkan data dari sensor yang dideteksi oleh sensor MLX90614 dan sensor ultrasonik sedangkan Buzzer berfungsi untuk menandakan data dari input telah diolah oleh NodeMCU, buzzer juga berfungsi untuk menandakan apabila objek yang dideteksi suhunya lebih dari $380 \mathrm{C}$.
Broker MQTT yang digunakan pada sistem ini adalah HiveMQ, data yang telah diperoleh dari sensor ultrasonik dan sensor MLX90614 akan dikirimkan oleh NodeMCU ke broker MQTT, kemudian akan dikirimkan lagi ke Thingsboard IoT Platfrom. Untuk melihat data yang dideteksi oleh sensor ultrasonik dan sensor MLX90614 yang diperoleh Thingsboard, user dapat melihatnya pada web UI di Thingsboard IoT platform.

\section{B. Diagram Alir Sistem}

Gambar 5 adalah diagram alir untuk menjelaskan sitem pemeriksaan suhu tubuh dan jumlah orang masuk gedung. Keterangan diagram alir : 
1) Inisialisasi program, program pada NodeMCU diinisialisasi.

2) NodeMCU koneksi ke WiFi, mengkoneksikan NodeMCU dengan memilih jaringan wireless dan memasukan password yang sesuai.

3) Membaca sensor ultrasonik, sensor ultrasonik mendeteksi objek yang lewat dan menghitung berapa objek yang memasuki gedung. Membaca sensor MLX90614, sensor MLX90614 mengukur suhu tubuh tanpa harus mengenai bagian tubuh orang yang dideteksi.

4) Mengambil data suhu dan jumlah orang, NodeMCU menerima data suhu dan jumlah orang dari input sensor MLX90614 dan sensor ultrasonik.

5) Kirim data ke broker MQTT HiveMQ, NodeMCU mempublish atau mengirimkan data ke MQTT broker.

6) Konfigurasi HiveMQ, mengkonfigurasikan broker MQTT HiveMQ dengan menambahkan host dan memilih port yang digunakan.

7) Chart proses Thingsboard, proses login dan menyiapkan device pada Thingsboard.

8) Integrasi MQTT merubah data menjadi telemetry di Thingsboard.

9) Pada Web User Interface yang terdapat pada IoT platform Thingsboard, User mensubcribe atau menrima data dari MQTT broker, user dapat melihat data yang telah dipublish oleh devices.

NodeMCU mengkoneksikan dengan jaringan internet supaya data yang dideteksi sensor dapat di proses oleh NodeMCU. Input dari sistem ini adalah suhu tubuh dan orang yang akan dideteksi oleh sensor ultrasonik yang akan menghitung jumlah orang masuk ke dalam dan sensor MLX90614 akan mendeteksi suhu tubuh orang yang masuk ke dalam gedung. NodeMCU memproses semua masukan dari suhu tubuh dan orang yang dideteksi oleh sensor dan akan mengirimkan data dengan protokol MQTT.

Pada broker MQTT dikonfigursi topic yang akan diambil, lalu host dan port yang akan digunakan oleh sistem pemeriksaan suhu dan jumlah orang. NodeMCU mempublish data suhu tubuh dan jumlah yang telah diproses dan broker MQTT HiveMQ menerima data suhu tubuh dan jumlah orang dari NodeMCU. Broker MQTT akan mempublish data apabila ada yang mensubscribe.

Thingsboard IoT platform sebagai subscriber akan menerima data dari broker MQTT. Thingsboard juga bertugas sebagai platform untuk pemrosesan data yang telah dikim oleh broker MQTT. Data suhu tubuh dan jumlah orang akan divisualisasikan oleh dashboard Thingsboard.

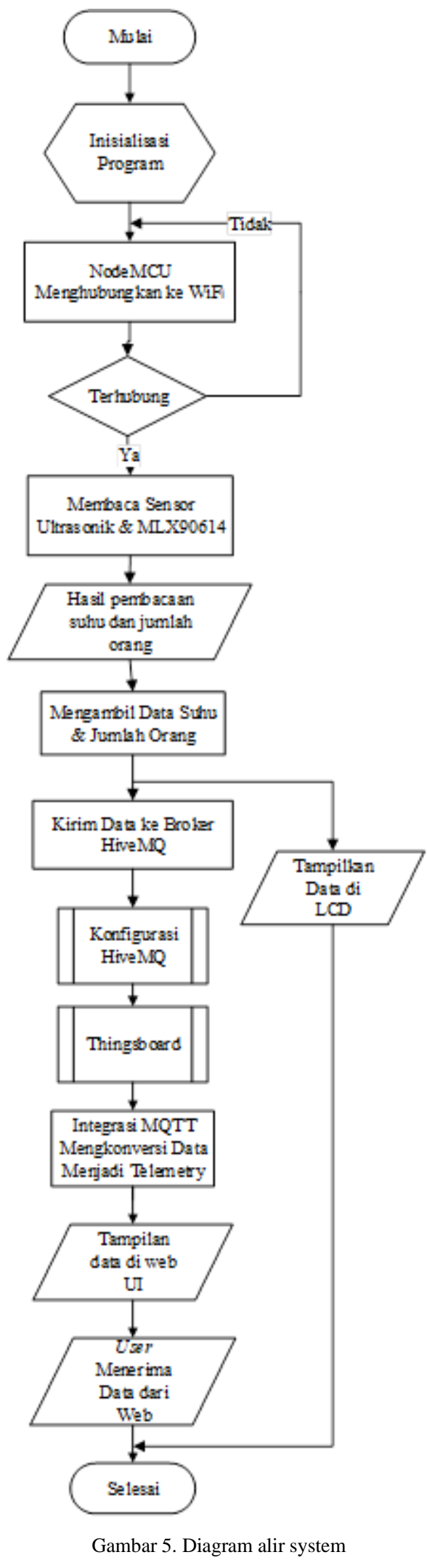

C. Arsitektur IoT

Berikut ini pada Gambar 6 adalah arsitektur IoT pada system pemeriksaan suhu dan jumlah orang masuk. 


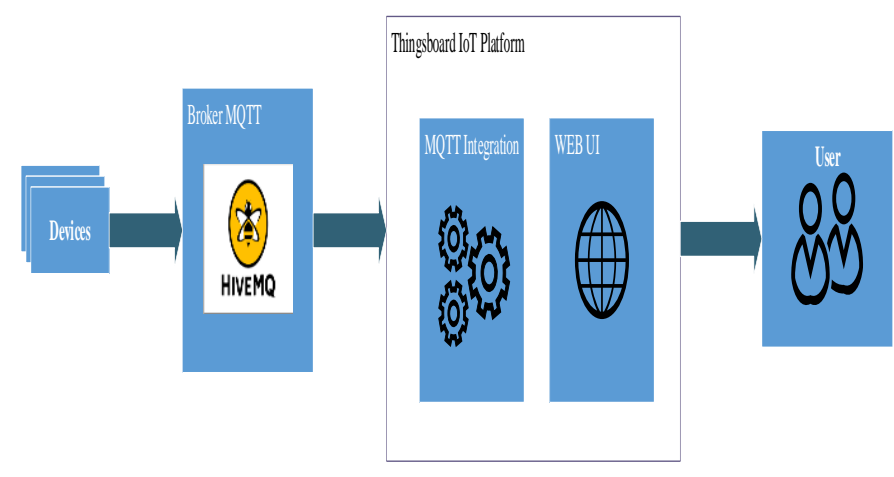

Gambar 6. Arsitektur IoT

Pada arsitektur di Gambar 6, menggunakan Thingsboard sebagai platform IoT. Thingsboard IoT platform digunakan sebagai pengumpulan, pemrosesan dan sebagai visualisasi. Data-data yang dikumpulkan adalah data yang dikirim oleh device menggunakan protokol MQTT. Data lalu di proses oleh MQTT integration pada Thingsboard IoT platform, data yang telah diproses akan divisualisasikan oleh Web UI pada Thingsboard.

Pada Gambar 3, device yang merupakan perangkat keras yang terdiri dari input sensor MLX90614 dan sensor ultrasonik, mikrokontroler nodeMCU dengan modul WiFi ESP8266, dan output yang terdiri dari LCD dan buzzer. Dari diagram skematik sistem diatas dapat dilihat devices mempublish atau mengirim data ke broker MQTT HiveMQ dan IoT platform Thingsboard menerima data dari broker MQTT dan juga terdapat Web User Interface dari data yang dikirm devices. Pada protokol MQTT menggunakan metode komunikasi publish dan subscribe. MQTT server atau disebut MQTT broker merupakan sebuah pusat pengiriman atau penerimaan data antara pengirim dan penerima. Untuk devices dapat mempublish data, sebuah devices harus mempunyai topic yang sama supaya devices dapat mengirim data ke MQTT broker. MQTT broker berperan sebagai subscriber dari devices dan publisher untuk user. User berperan sebagai subscriber atau menerima data dari devices yang telah dipublish atau dikirim oleh MQTT broker.

\section{Perancangan Perangkat Keras}

Pada perancangan perangkat keras, NodeMCU digunakan sebagai pengendali dan penghubung dengan internet, NodeMCU terhubung dengan semua sensor - sensor yang digunakan dalam perancangan perangkat keras. Komponen yang digunakan lainya terdiri dari, sensor ultrasonik sebagai input yang berfungsi untuk menghitung jumlah orang yang masuk ke dalam gedung. Komponen lainya yaitu sensor suhu MLX90614, sebagai input yang berfungsi untuk mendeteksi suhu orang yang masuk kedalam gedung. LCD sebagai penampil data yang diterima oleh NodeMCU dan buzzer berfungsi sebagai tanda bahwa data telah dipublish oleh devices. Berikut adalah perancangan perangkat keras pada sistem pemeriksa suhu tubuh dan jumlah orang masuk:

1) Perancangan Sensor Ultrasonik

Pada perancangan ini sensor ultrasonik sebagai input untuk menghitung jumlah orang masuk ke dalam gedung, terdapat 4 kaki yang dihubungkan dengan NodeMCU yaitu VCC, Triger, Echo dan Ground.

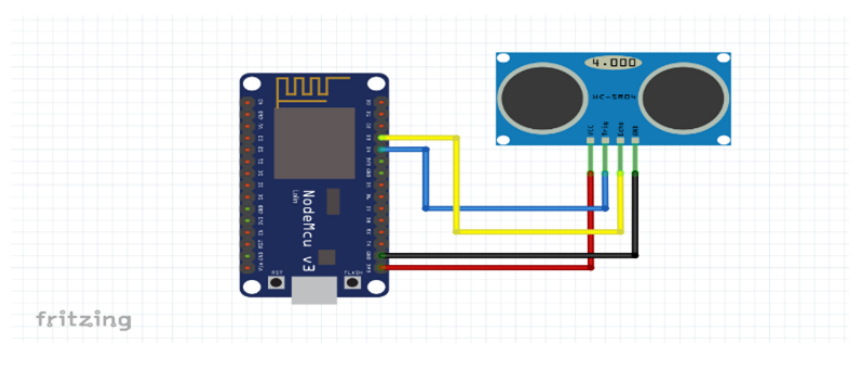

Gambar 7. Perancangan ultrasonic

Keterangan pada gambar, Kabel Merah $=$ VCC, Kabel Hitam = Ground, Kabel Biru = Triger $($ pin D4), Kabel Kuning = Echo (pin D3). Pada Gambar 4 terdapat wiring sensor ultrasonik yang dihubungkan ke NodeMCU, yaitu kabel merah dihubungkan ke VCC, kabel hitam ke Ground, kabel berwarna biru sebagai pin triger dihubungkan ke pin D4 pada NodeMCU dan kabel berwarna kuning pin echo dihubungkan ke pin D3.

2) Perancangan Sensor MLX90614

Pada perancangan sensor suhu MLX90614 sebagai input untuk mendeteksi suhu tubuh orang yang masuk ke dalam gedung. Terdapat 4 kaki yang dihubungkan ke NodeMCU, yaitu VCC, Ground, SCL dan SDA.

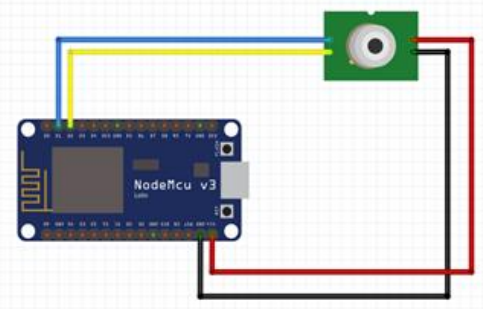

fritzing

Gambar 8. Perancangan sensor suhu MLX90614

Keterangan pada gambar 8, Kabel Merah = VCC, Kabel Hitam = Ground, Kabel Biru = SCL (pin D1), Kabel kuning = SDA (pin D2). Pada Gambar 5 terdapat sensor suhu MLX90614 yang dihubungkan pada NodeMCU, dengan kabel merah dihubungkan ke pin power yaitu VCC, kabel hitam pada Ground dan biru sebagai SCL ke pin D1 dan kabel kuning sebagai SDA dihubungkan ke pin D2 pada NodeMCU.

3) Perancangan $L C D$

Pada perancangan ini, LCD sebagai output untuk menampilkan data suhu tubuh dan jumlah orang yang masuk ke dalam gedung. Terdapat 4 kaki yang dihubungkan ke NodeMCU, yaitu VCC, Ground, SCL dan SDA.

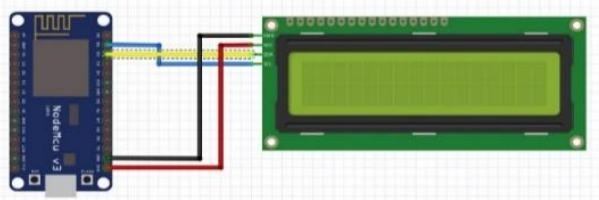

Gambar 9. Perancangan LCD 
Keterangan pada gambar, Kabel Merah $=$ VCC, Kabel Hitam = Ground, Kabel Biru = SCL (pin D1), d. Kabel kuning = SDA (pin D2). Pada Gambar 6 terdapat oputput LCD yang dihubungkan pada NodeMCU, dengan kabel merah dihubungkan ke pin power yaitu VCC, kabel hitam pada Ground dan biru sebagai SCL ke pin D1 dan kabel kuning sebagai SDA dihubungkan ke pin D2 pada NodeMCU.

4) Perancangan Buzzer

Pada perancangan buzzer, buzzer digunakan sebagai output untuk pemberitahuan jikalau data suhu tubuh dan jumlah orang masuk telah dipublish oleh devices. Terdapat 2 kaki yang dihubungkan buzzer ke NodeMCU, yaitu Ground dan Data.

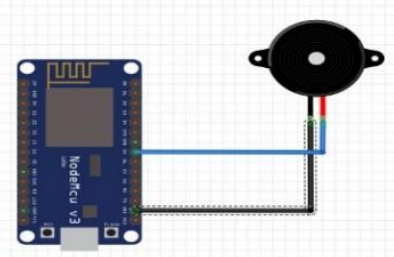

fritzing

Gambar 10. Perancangan buzzer

Keterangan pada gambar, Kabel Biru = Data, Kabel Hitam = Ground. Pada Gambar 3.7 terdapat buzzer sebagai output dari devices, dengan kabel biru sebagai data dan VCC dari NodeMCU dan kabel hitam sebagai Ground.

5) Intergrasi Perangkat Keras

Pada perancangan kali ini adalah rancangan keseluruhan dari sistem pemeriksa suhu tubuh dan jumlah orang masuk.

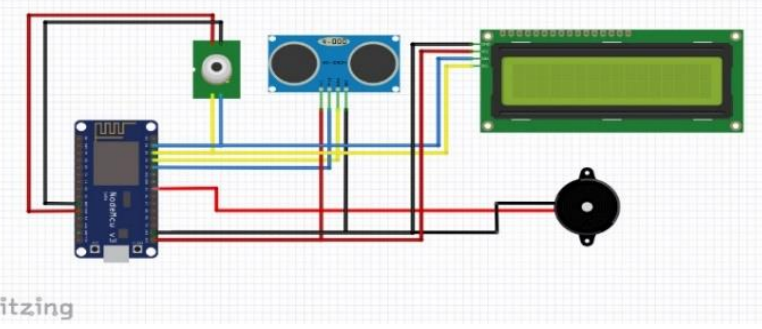

Gambar 11. Intergrasi perangkat keras

Gambar 8 adalah rangkaian keseluruhan dari sistem yang dibuat, rangkaian tersebut memiliki 2 sensor sebagai input, memiliki 1 pengendali, LCD dan buzzer sebagai output.

E. Perancangan Software

Pada perancangan ini, software yang digunakan adalah Arduino IDE yang digunakan untuk memprogram NodeMCU, HiveMQ sebagai broker MQTT yang digunakan dan Thingsboard IoT platform sebagai media untuk mevisualisasikan data.

1) Perancangan Software pada Arduino IDE

Untuk memprogram NodeMCU memerlukan software Arduino IDE, supaya NodeMCU dapat menjalankan program system pemeriksaan suhu tubuh dan jumlah orang.

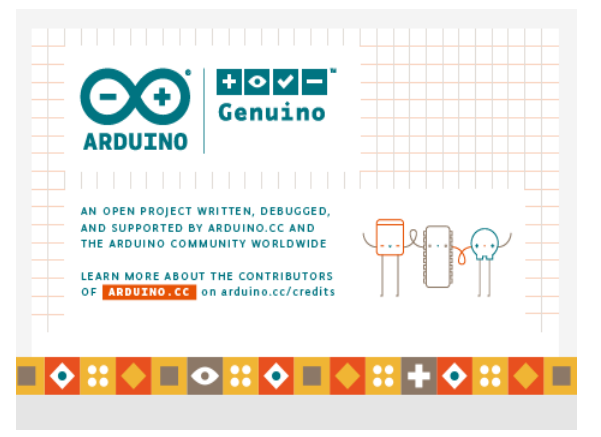

Gambar 12. Software arduino IDE

Pada proses pembuatan program di Arduino IDE, program yang di compaile terlebih dahulu supaya software dapat mendeteksi apabila ada program yang salah. Setelah mengetahui jikalau tidak ada program yang salah program yang telah dibuat diupload ke board NodeMCU.

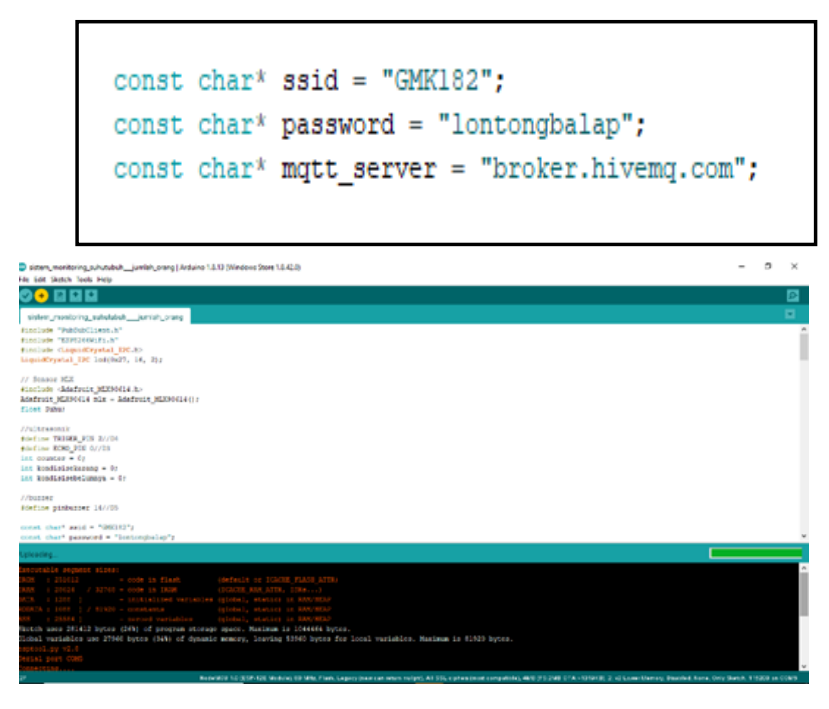

Gambar 13. Proses upload program ke NodeMCU

Gambar 10 adalah proses upload program dari Arduino IDE ke NodeMCU, apabila proses upload berhasil program pada Arduino IDE telah tersimpan pada mikrokontroler NodeMCU dan NodeMCU dapat menjalankan program sistem pemeriksa suhu tubuh dan jumlah orang masuk.

2) Perancangan Protokol MQTT

Protocol MQTT pada sistem ini digunakan sebagai protokol pengirim data antara publisher yaitu device yang dibuat, broker MQTT HiveMQ dan Thingsboard IoT platform mensubcribe data dari broker HiveMQ.

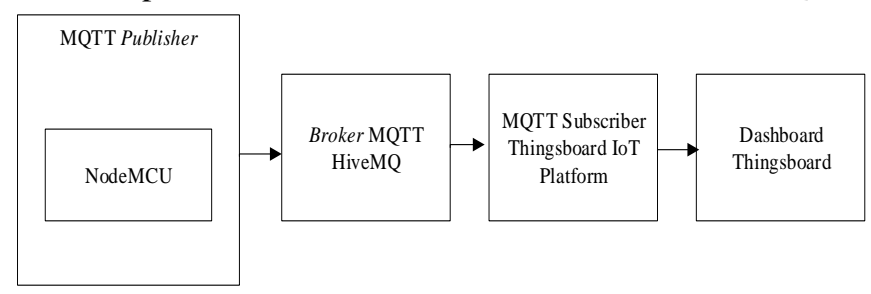

Gambar 14. Mekanisme protokol MQTT 
Pada Gambar 14 merupakan mekanisme pengiriman data menggunakan protokol MQTT. Pada bagian MQTT publisher pada sistem ini NodeMCU yang terdiri dari input sensor MLX90614, sensor ultrasonik. HiveMQ befungsi sebagai broker yang mengatur penerimaan data dari NodeMCU sebagai publisher, Thingsboard IoT platform berfungsi sebagai subscriber yang meminta topic data. Pengiriman data dalam protokol MQTT menggunakan format json dikarenakan format json sangan mudah dibaca dan lebih ringan dalam transfer data antara server dan klien.

MQTT menggunakan broker HiveMQ dengan host broker.hivemq.com. Device mengirim data dari sensor yaitu data suhu tubuh dan jumlah orang, dimana data dikirim menggunakan protokol MQTT ke broker MQTT HiveMQ dengan format json. Setelah format data diterima oleh broker MQTT HiveMQ, Thingsboard akan mensubscribe untuk memperoleh data suhu tubuh dan perhitungan jumlah orang dari broker MQTT.

Pada mekanisme protokol MQTT di Gambar 14, dapat dilihat bahwa MQTT publisher yaitu NodeMCU atau device yang telah dirangcang mengirim data suhu dan jumlah orang dari input sensor. Data dikirim ke broker MQTT HiveMQ dengan berupa format json, data suhu dan jumlah orang lalu di subscribe oleh IoT platform Thingsboard. Data yang tadinya berupa format json dirubah menjadi telemetry oleh Thingsboard, data suhu dan jumlah orang dapat dilihat dalam bentuk tabel pada dashboard Thingsboard IoT platrform. Berikut merupakan penerapan protokol MQTT pada program Arduino ide

Pemilihan jarigan internet dan server MQTT

Pada Gambar 15 merupakan program untuk pemilihan SSID yang akan digunakan oleh device. Pada protokol ini digunakan broker MQTT yaitu broker.hivemq.com untuk mempublish data suhu dan jumlah orang.

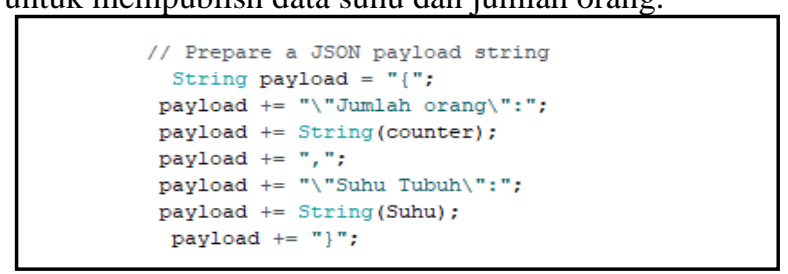

Gambar 15. Menyiapkan json payload string

Gambar 15 merupakan program untuk mengirimkan data ke broker MQTT dengan format json. Dalam program tersebut akan mengirimkan data jumlah orang dan suhu tubuh, dimana counter merupakan hasil dari pembacaan sensor ultrasonik dan suhu merupakan hasil pembacaan dari sensor MLX90614.

Pada Gambar 14 adalah program untuk pengiriman data ke broker MQTT HiveMQ, dengan topic "tb/mqttintegration/sensor/NodeMCU/temperature”.

Thingsboard IoT platform akan mensubscribe atau menerima data dari broker MQTT dengan topic "tb/mqtt-integration/sensor/NodeMCU/temperature".

Setelah pengiriman data berhasil buzzer akan memberikan tanda dan pengiriman data diberi delay 5 detik.

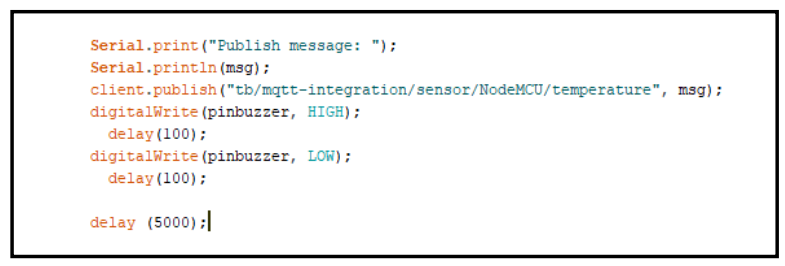

Gambar 16. Pengiriman data suhu tubuh dan jumlah orang

\section{F. Perancangan Web Thingsboard}

Pada IoT platform Thingsboard telah mempunyai infrastruktur di sisi server, yang terdiri dari database, MQTT broker dan web server yang juga terdapat dashboard. Pada sistem pemeriksa suhu tubuh dan jumlah orang, menggunakan MQTT broker dan web server yang ada pada IoT platform Thingsboard. Berikut adalah perancangan web Thingsboard:

1) Proses login ke Thingsboard.

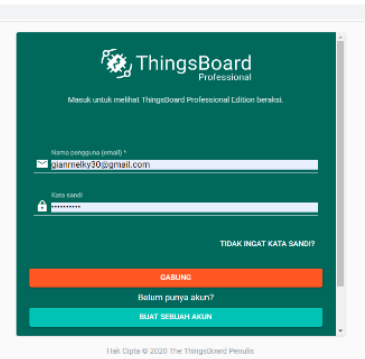

Gambar 17 Halaman login thingsboard

Gambar 17 merupakan halaman login pada thingsboard, untuk dapat login ke Thingsboard harus mempunyai email dan password yang telah terverifikasi oleh Thingsboard, dengan mendaftar terlebih dahulu di halaman signup.

2) Pembuatan device di Thingsboard

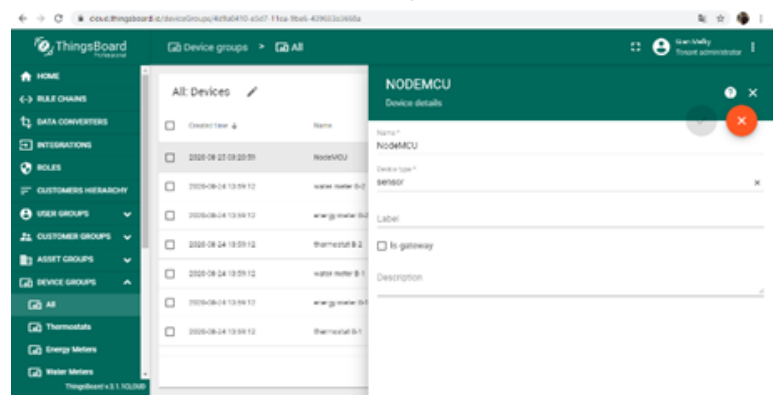

Gambar 18. Proses membuat device

Pada proses pembuatan device berinama device dan isi tipe device tersebut.

3) Pembuatan dashboard

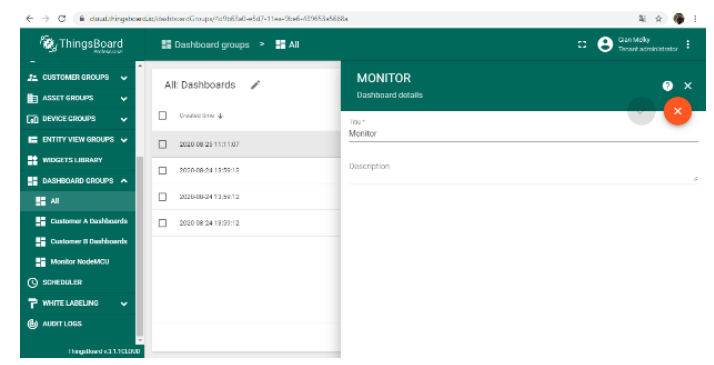

Gambar 19. Proses pembuatan dashboard 
Pada proses pembuatan dashboard isi title untuk menamai dashboard.

4) Penambahan Widget Pada Dashboard

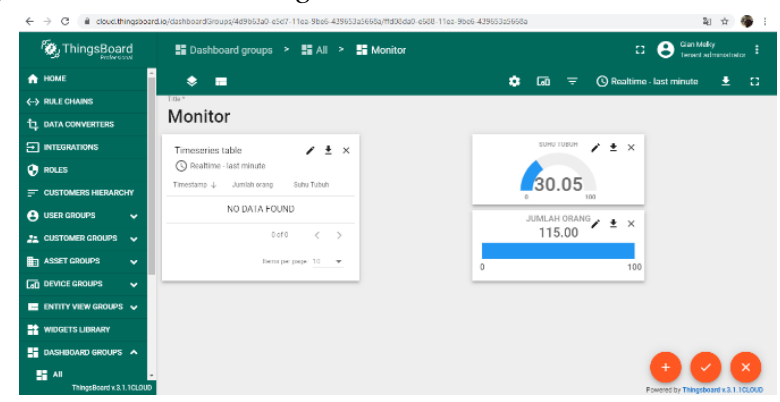

Gambar 20. Widget pada dashboard

Dalam Gambar 18 yaitu terdiri halaman pembuatan dashboard dan setting widget, pada halaman pembuatan dashboard widget ditambahkan yang terdiri dari tampilan tabel suhu tubuh dan jumlah orang, tampilan suhu tubuh dan tampilan jumlah orang. Setiap widget disetting agar dapat menerima data dari device yang terdiri dari jumlah orang dan suhu tubuh.

5) Membuat Dashboard Supaya Dapat Diakses Public

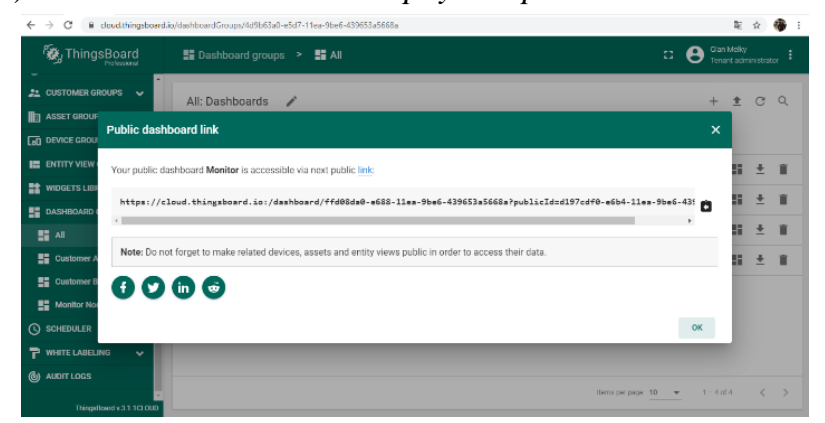

Gambar 21. Proses membuat dashboard dapat diakses public

Pada Gambar 19 Dashboard telah dapat diakses oleh public dengan mengakses link yang terdapat pada dashboard Thingsboard.

6) Membuat MQTT Inetgration

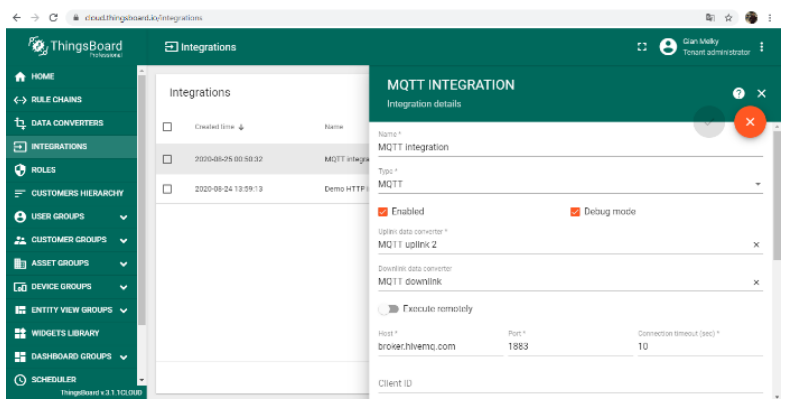

Gambar 22. Proses membuat MQTT Integration

Tujuan dari pembuatan integrase MQTT adalah supaya Thingsboard dapat menerima data suhu tubuh dan jumlah orang pada broker MQTT HiveMQ. Untuk dapat menrima data dari broker MQTT, integrasi MQTT pada Thingsboard harus menuliskan topic yang sesuai dengan apa yang akan diambil datanya.
7) Membuat MQTT Uplink

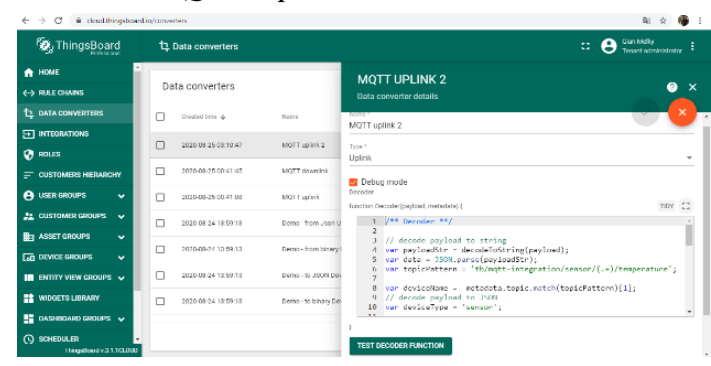

Gambar 23. Proses membuat MQTT uplink

Tujuan dari pembuatan MQTT uplink adalah untuk mengkonversi data json yang dikirm oleh broker MQTT supaya dapat menjadi telemetry untuk data dikim ke dashboard di Thingsboard.

\section{HASIL DAN PEMBAHASAN}

A. Pengujian Sensor MLX90614

Pada pengujian sensor MLX90614 ini dilakukan sebanyak 10 kali dengan membandingkan data hasil sensor MLX90614 dengan sensor pada Thermometer Gun merk Coolpad, berikut data hasil pengujian:

Tabel 4. Pengujian sensor MLX90614

\begin{tabular}{|c|c|c|c|}
\hline No & $\begin{array}{c}\text { Sensor } \\
\text { MLX90614 } \\
\left({ }^{\circ} \mathrm{C}\right)\end{array}$ & $\begin{array}{c}\text { Thermometer } \\
\text { Gun }\left({ }^{\circ} \mathrm{C}\right)\end{array}$ & $\begin{array}{c}\text { Selisih } \\
\text { Suhu } \\
\left({ }^{\circ} \mathrm{C}\right)\end{array}$ \\
\hline 1 & 33,85 & 33,9 & 0,05 \\
\hline 2 & 34,23 & 34,7 & 0,47 \\
\hline 3 & 33,23 & 34 & 0,77 \\
\hline 4 & 33,93 & 34,6 & 0,67 \\
\hline 5 & 33,90 & 34,1 & 0,2 \\
\hline 6 & 34,17 & 34,6 & 0,43 \\
\hline 7 & 34,21 & 35 & 0,79 \\
\hline 8 & 34,67 & 35 & 0,83 \\
\hline 9 & 33,97 & 34,2 & 0,33 \\
\hline 10 & 33,71 & 34,2 & 0,49 \\
\hline \multicolumn{3}{|c|}{ Nilai rata-rata selisih suhu } & 0,5 \\
\hline
\end{tabular}

Sensor MLX90614 Thermometer Gun

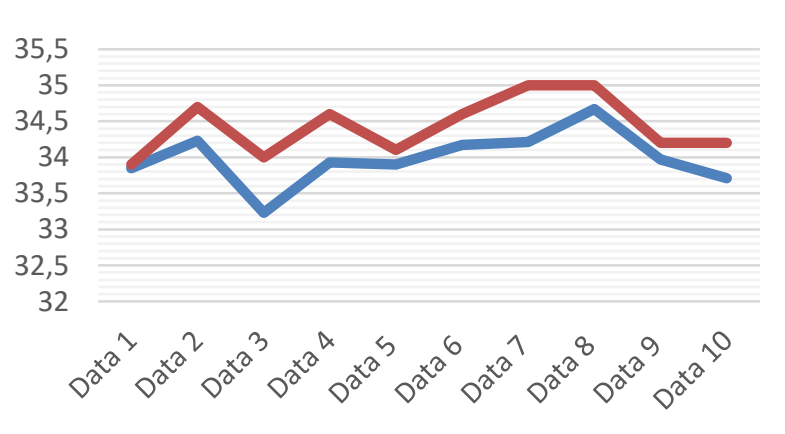

Gambar 24. Grafik hasil pengujian sensor MLX90614

Berdasarkan data pada Gambar 22 maka dapat disimpulkan hasil dari sensor MLX90614 yang dibandingkan dengan thermometer gun menampilkan perbandingan dengan selisih hasil yang tidak terlalu jauh dengan rata-rata $0,5^{\circ} \mathrm{C}$, dengan demikian sensor MLX 90614 berfungsi. 


\section{B. Pengujian Sensor MLX90614 dan Thermometer Gun} Berdasarkan Jarak

Tabel 5. Pengujian jarak pada sensor MLX90614 dan thermometer gun

\begin{tabular}{|c|c|c|c|c|}
\hline No & $\begin{array}{c}\text { Jarak } \\
(\mathrm{cm})\end{array}$ & $\begin{array}{c}\text { Sensor } \\
\text { MLX90614 } \\
\left({ }^{\circ} \mathrm{C}\right)\end{array}$ & $\begin{array}{c}\text { Thermometer } \\
\text { Gun }\left({ }^{\circ} \mathrm{C}\right)\end{array}$ & $\begin{array}{c}\text { Selisih } \\
\left({ }^{\circ} \mathrm{C}\right)\end{array}$ \\
\hline 1 & $1 \mathrm{~cm}$ & 35,69 & 36,1 & 0,41 \\
\hline 2 & $2 \mathrm{~cm}$ & 35,37 & 35,8 & 0,43 \\
\hline 3 & $3 \mathrm{~cm}$ & 34,99 & 35,4 & 0,41 \\
\hline 4 & $4 \mathrm{~cm}$ & 34,51 & 35,1 & 0,59 \\
\hline 5 & $5 \mathrm{~cm}$ & 34,11 & 34,6 & 0,49 \\
\hline 6 & $6 \mathrm{~cm}$ & 33,91 & 34,3 & 0,39 \\
\hline 7 & $7 \mathrm{~cm}$ & 33,31 & 33,9 & 0,59 \\
\hline 8 & $8 \mathrm{~cm}$ & 32,77 & 33,2 & 0,43 \\
\hline 9 & $9 \mathrm{~cm}$ & 32,25 & 32,7 & 0,45 \\
\hline 10 & $10 \mathrm{~cm}$ & 32,15 & 32,7 & 0,55 \\
\hline 11 & $11 \mathrm{~cm}$ & 31,81 & 32,3 & 0,49 \\
\hline 12 & $12 \mathrm{~cm}$ & 31,63 & 32,1 & 0,47 \\
\hline \multicolumn{5}{|c|}{ Nilai rata-rata selisih suhu } \\
\hline \multicolumn{5}{|c|}{} \\
\hline
\end{tabular}

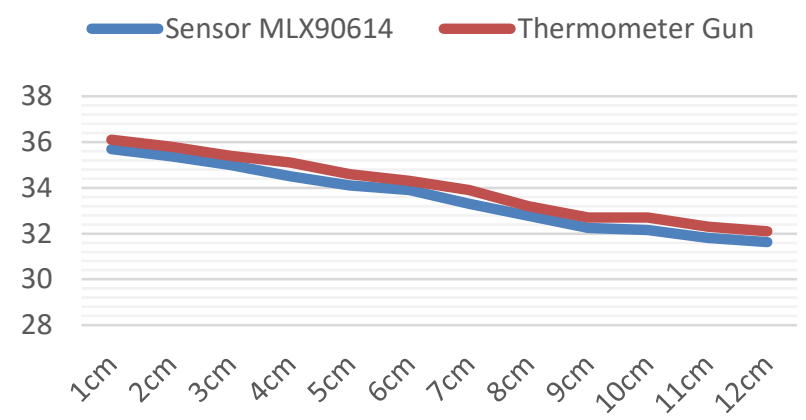

Gambar 25. Grafik Pengujian jarak sensor MLX90614 dan thermometer gun

Berdasarkan data pada tabel 23 jarak yang disarankan untuk melakukan pengukuran suhu tubuh pada jarak $1-4 \mathrm{~cm}$. Semakin dekat objek terhadap sensor maka semakin tinggi suhu pada objek. Pengujian dilakukan dengan satu orang yang sama pada jarak berbeda yaitu $1 \mathrm{~cm}$ sampai dengan $12 \mathrm{~cm}$.

\section{Pengujian Penghitungan Orang}

Pengujian penghitungan orang dapat dilihat pada Gambar 26.

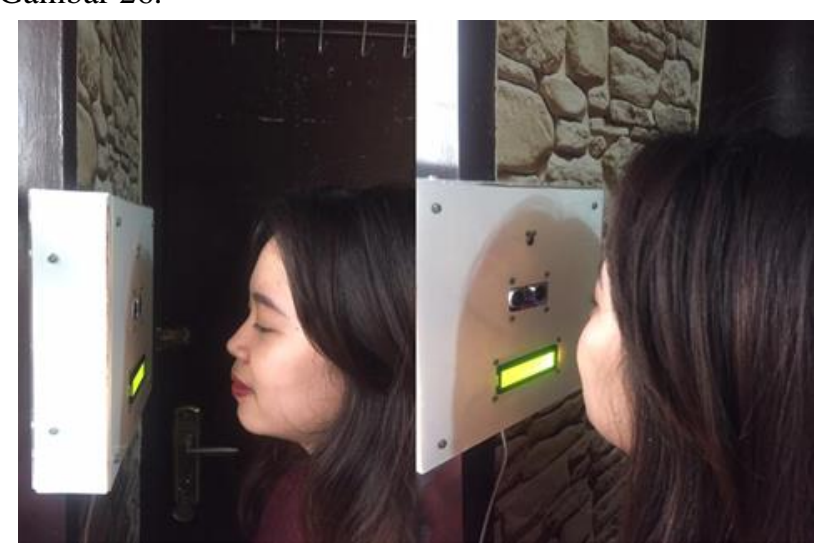

Gambar 26. Pengujian penghitungan orang

Pada Gambar 26 pengujian penghitungan orang, penghitungan orang di deteksi oleh sensor ultrasonik.
Tabel 6. Jarak jangkauan sensor ultrasonik

\begin{tabular}{|c|c|c|}
\hline No & $\begin{array}{c}\text { Jarak jangkauan } \\
\text { sensor ultrasonik }\end{array}$ & Status \\
\hline 1 & $2 \mathrm{~cm}$ & Terdeteksi \\
\hline 2 & $4 \mathrm{~cm}$ & Terdeteksi \\
\hline 3 & $6 \mathrm{~cm}$ & Terdeteksi \\
\hline 4 & $8 \mathrm{~cm}$ & Terdeteksi \\
\hline 5 & $10 \mathrm{~cm}$ & Tidak terdeteksi \\
\hline 6 & $12 \mathrm{~cm}$ & Tidak terdeteksi \\
\hline 7 & $14 \mathrm{~cm}$ & Tidak terdeteksi \\
\hline 8 & $16 \mathrm{~cm}$ & Tidak terdeteksi \\
\hline 9 & $18 \mathrm{~cm}$ & Tidak terdeteksi \\
\hline 10 & $20 \mathrm{~cm}$ &
\end{tabular}

Berdasarkan data Tabel 6 jarak terjauh yang dapat dideteksi sensor ultrasonik pada sistem ini adalah $10 \mathrm{~cm}$. Penghitungan jumlah orang dilakukan pada pintu masuk suatu gedung. Mekanisme dari penghitungan orang harus dilakukan dengan mengantri pada saat memasuki gedung. Apabila buzzer telah berbunyi berarti penghitungan orang tersebut telah selesai. Data dari penghitungan orang akan tampil pada web Thingsboard dan tampil pada LCD. Berikut Gambar 27 menunjukan tampilan penghitungan orang pada LCD.

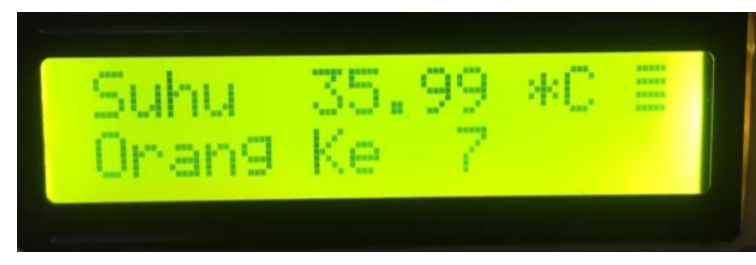

Gambar 27. Tampilan LCD

\section{Pengujian Pengiriman Data}

Pengujian ini dilakukan untuk menunjukkan jumlah waktu pengiriman data dari sistem pemeriksa suhu dan jumlah orang menggunakan webserver Thingsboard.

Tabel 7. Hasil pengiriman data

\begin{tabular}{|c|c|c|c|}
\hline No & $\begin{array}{c}\text { Waktu } \\
\text { Pengiriman }\end{array}$ & $\begin{array}{c}\text { Waktur Tampil } \\
\text { di Thingsboard }\end{array}$ & $\begin{array}{c}\text { Selisih } \\
\text { dalam } \\
\text { detik }\end{array}$ \\
\hline 1 & 21.52 .48 & 21.52 .49 & 1 \\
\hline 2 & 21.52 .56 & 21.52 .56 & 0 \\
\hline 3 & 21.53 .03 & 21.53 .03 & 0 \\
\hline 4 & 21.53 .08 & 21.53 .10 & 1,2 \\
\hline 5 & 21.53 .16 & 21.53 .16 & 0 \\
\hline 6 & 21.53 .23 & 21.53 .23 & 0 \\
\hline 7 & 21.53 .30 & 21.53 .30 & 0 \\
\hline 8 & 21.53 .36 & 21.53 .37 & 1 \\
\hline 9 & 21.53 .43 & 21.53 .43 & 0 \\
\hline 10 & 21.53 .48 & 21.53 .50 & 1,2 \\
\hline \multicolumn{3}{|c|}{ Rata-Rata } & 0,44 \\
\hline
\end{tabular}


Pada Tabel 4 merupakan hasil pengujian pengiriman data secara keseluruhan. Pada proses pengiriman data terdapat selisih waktu. Selisih tersebut merupakan waktu pengiriman data dari publisher menuju ke server Thingsboard. Dari proses pengujian yang sudah dilakukan dapat diketahui bahwa setelah dilakukan 10 kali pengujian menghasilkan rata-rata delay pengiriman data dalam sistem pemeriksa suhu dan tubuh orang adalah 0,44 detik. Pada sistem ini waktu yang dibutuhkan untuk mendeteksi perubahan suhu dan jumlah orang pada sensor hingga data ditampilkan pada server Thingsboard adalah 0,44 detik.

\section{KESIMPULAN}

Perancangan pada sistem ini menggunakan dua sensor yaitu sensor MLX90614 dan sensor ultrasonic. Berdasarkan pengujian pada sensor MLX90614 maka bisa disimpulkan hasil dari sensor MLX90614 yang dibandingkan dengan thermometer gun menampilkan perbandingan dengan selisih hasil dengan rata-rata $0.5^{\circ} \mathrm{C}$, dengan demikian sensor MLX 90614 dapat digunakan. Sedangkan untuk sensor ultrasonik dapat menghitung jumlah orang dapat dilihat di LCD dan webserver thingsboard. Setelah di lakukan pengujian pengiriman data sebanyak $10 \mathrm{kali}$, rata - rata waktu yang di butuhkan sistem untuk mengirim data ke Thingsboard adalah 0,44 detik. Protokol MQTT untuk komunikasi device dengan UI dapat direalisasikan menggunakan MQTT broker HiveMQ dengan menentukan device sebagai publisher ke broker HiveMQ dan smarthphone atau PC sebagai subscriber. Perancangan sistem keseluruhan berbasis IoT menggunakan protokol MQTT telah diuji dan telah bekerja dengan baik sesuai konsep arsitektur MQTT berupa data yang dikirimkan yaitu data suhu tubuh dan jumlah orang yang dikimkan oleh device ke broker HiveMQ berhasil ditampilkan pada dashboard Thingsboard IoT platform..

\section{REFERENSI}

[1] Ni Komang Suni Astini, "Tantangan Dan Peluang Pemanfaatan Teknologi Informasi Dalam Pembelajaran Online Masa Covid-19," Jurnal Ilmu Pendidikan, vol. 3, no. 2, hal. 241-255, 2020.

[2] Dalinama Telaumbanua, "Urgensi Pembentukan Aturan Terkait Pencegahan Covid-19 di Indonesia," Jurnal Pendidikan, Sosial, dan Agama., vol. 12, no. 1, hal. 59-70, 2020.

[3] Husna Ni'matul Ulya, “Alternatif Strategi Penanganan Dampak Ekonomi Covid-19 Pemerintah Daerah Jawa Timur Pada Kawasan Argopolitan," Journal of Islamic Economic and Business, vol.3, no. 1, hal.80-109, 2020.

[4] Dwizka Krisnawati, dkk. "Ketahana Negara Republik Indonesia Masa Pandemik Covid-19," Jurnal Global Citizen, vol. 9, no. 1, hal. 63-70, 2020.

[5] Neneng Nurhalimah. "Upaya Bela Negara Melalui Sosial Distancing dan Lockdown Untuk Mengatasi Wabah Covid-19," 15 April 2020. [Online]. Available at SSRN: https://ssrn.com/abstract=3576405 [Accessed 24 Agustus 2020].

[6] Wahyu Oktavia, Nur Hayati, "Pola Karakteristik Ragam Bahasa Istilah Padamasa Pandemi Covid 19 (Corona Virus Disease 2019)," Jurnal Bahasa, Sastra, dan Pengajarannya, vol. 1, no. 1, hal.1-15, 2020.

[7] Agung Nurrahman. "Peran Pemerintah Daerah dalam Memelihara Ketenteraman dan Keterlibatan Umum
(Studi Pada Penanganan Penyebaran Virus Covid-19 Di Provinsi DKI Jakarta)', Jurnal Tatapamong, vol. 2, no. 1, hal. 1-16, Maret 2020.

[8] Destivanesha Rina, "Pencengahan Penyebaran Virus Corona Di Bandara Menggunakan Artifical Intellegence," STRING (Satuan Tulisan Riset dan Inovasi Teknologi), vol. 5, no. 1, hal. 94-100, Agustus 2020.

[9] Heady Dianty, "Mendeteksi Suhu Tubuh Menggunakan Infrared dan Arduino," Jurnal Ilmu Komputer (JIK), vol. III, no. 03, Agustus 2020.

[10] Sahya Anggara, Salamatul Afiyah, Ai Siti Farida, Jaliludin Muslim. "Inovasi Kebijakan Publik Tentang Pencegahan Dan Penanggulangan Corona Virus Disease 19 (Covid-19) Di Jawa Barat.” 2020.

[11] Handoko R. , Susanto Sambasri, Dede Irawan Saputra, Nana Heryana, Agus Purwadi, Marsudiono, "IoT Application for On-line Monitoring of $1 \mathrm{kWp}$ Photovoltaic System Based on NodeMCU ESP8266 and Android Application," IEEE, 2019 2nd International Conference on High Voltage Engineering and Power Systems (ICHVEPS), pp. 230-234.

[12] Handoko Rusiana Iskandar, Hermadani Hermadani, Dede Irawan Saputra, Hajiar Yuliana, "Eksperimental Uji Kekeruhan Air Berbasis Internet of Things Menggunakan Sensor DFRobot SEN0189 dan MQTT Cloud Server," Seminar Nasional Sains dan Teknologi 2019, pp. 2-9.

[13] Dede Irawan Saputra, Agus Rohmat, Asep Najmurrokhman, Zul Fakhri, "Implementation of fuzzy inference system algorithm in brooding system simulator with the concept of IoT and wireless nodes" IOP Conference Series: Materials Science and Engineering, 2019, Vol 830, No. 3, pp. 1-6

[13] Husnul Anwari, Eko Sakti Pramukantoro, M. Hannats Hanafi, "Pengembangan Iot MiddlewareBerbasis Event-Based dengan Protokol Komunikasi CoAP, MQTT dan Websocket," Jurnal Pengembangan Teknologi Informasi dan Ilmu Komputer, vol. 1, no. 12, hlm. 15601567, Desember 2017.

[14] Wisnu Adi Perdana. "Alat Pemantau Kondisi Seorang Gamer. " 2019.

[15] Achmad Fiqhi Ibadilla dkk. "Designing Magnetic Stirrer Hot Plate Using Contactless Infrared MLX90614 Temperature Sensor Based On PID Controller," Atlantis Highlights in Engineering (AHE), vol. 1, hal. 940-944, 2018.

[16] Putra Stevano Frima Yudha dan Ridwan Abdullah Sani. "Implementasi Sensor Ultrasonik HC-SR04 Sebagai Sensor Parkir Mobil Berbasis Arduino," Jurnal Hasil Penelitian Bindang Fisika, vol. 5, no. 3, hal. 19 - 26, 2017.

[17] Nasha Dewandra Putra. "Wireless Smart Tag Device Sebagai Sistem Keamanan Rumah Berbasis IoT". 2018.

[18] Deni Kurnia, Vina Widiasih. "Implementasi NodeMCU Dalam Prototipe Sistem Pemberian Pakan Ayam Otomatis dan Presisi Berbasis Web," Jurnal Teknologi, vol. 11, no.2, hal. 170-178, Juli 2019.

[19] Eko Ardiansyah, Hurriyatul Fitriyah, Dahnial Syauqy, "Sistem Penghitung Jumlah Orang Otomatis Pada Pintu Masuk Berbasis Sensor Ultrasonik dan Mikrokontroler Arduino Uno dengan Metode Bayes," Jurnal Pengembangan Teknologi Informasi dan Ilmu Komputer, vol. 3, no. 1, , hlm. 673-678, Januari 2019. 
[20] Budi Sumanto, Paulus Puliano, "Pengukuran Suhu Tubuh Secara Tak Sentuh menggunakan Inframerah Berbasis Arduino Uno," Seminar Nasional SAINSTEK Ke-2 Undana Tahun 2014, Kupang 15-16 Oktober 2014.

\section{BIOGRAFI PENULIS}

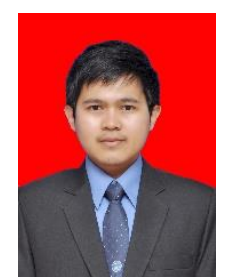

Dede Irawan Saputra, lahir di Purwakarta Tanggal 25 Juni 1991. Penulis meupakan lulusan Sarjana Pendidikan (S.Pd) Pendidikan Teknik Elektro dari Universitas Pendidikan Indonesia (UPI), kemudian melanjutkan studi Magister Teknik (M.T) di Sekolah Teknik Elektro dan Informatika (STEI) KK Kendali dan Sisetm Cerdas di Institut Teknologi Bandung (ITB)

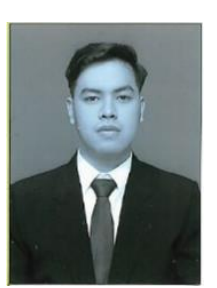

Gian Melky Karmel, lahir di Bandung Tanggal 20 September 1998. Penulis meupakan lulusan Sarjana Teknik (S.T) Teknik Elektro dari Universitas Jenderal Achmad Yani (UNJANI)

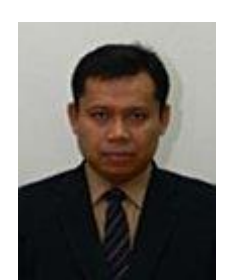

Yuda Bakti Zainal, lahir di Bandung Tanggal 5 Juni 1969. Penulis meupakan lulusan Sarjana Teknik (S.T) Teknik Elektro dari Universitas Jenderal Achmad Yani (UNJANI), kemudian melanjutkan studi Magister Teknik (M.T) di Sekolah Teknik Elektro dan Informatika (STEI) KK Kendali dan Sisetm Cerdas di Institut Teknologi Bandung (ITB) 